\title{
Layering Precision Land Leveling and Furrow Irrigated Raised Bed Planting: Productivity and Input Use Efficiency of Irrigated Bread Wheat in Indo-Gangetic Plains
}

\author{
M. L. Jat ${ }^{{ }^{*}}$, Raj Gupta ${ }^{1}$, Y. S. Saharawat ${ }^{2}$, Raj Khosla ${ }^{3}$ \\ ${ }^{1}$ International Maize and Wheat Improvement Centre (CIMMYT), NASC Complex, New Delhi, India; ${ }^{2}$ International Rice Research \\ Institute (IRRI), NASC Complex, New Delhi, India; ${ }^{3}$ Colorado State University, Fort Collins, USA. \\ Email: *M.Jat@cgiar.org
}

Received May 21 ${ }^{\text {st }}, 2011$; revised June 29 ${ }^{\text {th }}, 2011$; accepted July $18^{\text {th }}, 2011$.

\begin{abstract}
Stagnating yield and declining input use efficiency in irrigated wheat of the Indo-Gangetic Plain (IGP) coupled with diminishing availability of water for agriculture is a major concern of food security in South Asia. The objective of our study was to establish an understanding of how wheat yield and input use efficiency can be improved and how land leveling and crop establishment practices can be modified to be more efficient in water use through layering of precisionconservation crop management techniques. The "precision land leveling with raised bed" planting can be used to improve crop yield, water and nutrient use efficiency over the existing "traditional land leveling with flat" planting practices. We conducted a field experiment during 2002-2004 at Modipuram, India to quantify the benefits of alternate land leveling (precision land leveling) and crop establishment (furrow irrigated raised bed planting) techniques alone or in combination (layering precision-conservation) in terms of crop yield, water savings, and nutrient use efficiency of wheat production in IGP. The wheat yield was about $16.6 \%$ higher with nearly $50 \%$ less irrigation water with layering precision land leveling and raised bed planting compared to traditional practices (traditional land leveling with flat planting). The agronomic (AE) and uptake efficiency (UE) of $N, P$ and $K$ were significantly improved under precision land leveling with raised bed planting technique compared to other practices.
\end{abstract}

Keywords: Precision Land Leveling, Furrow Irrigated Raised Bed Planting, Input Use Efficiency, Irrigated, Bread Wheat, Water Productivity, Uptake Efficiency, Agronomic Efficiency

\section{Introduction}

Bread wheat (Triticum aestivum L.) is the most widely grown and consumed food crop and is the staple food for $35 \%$ of the world population [1]. The irrigated wheat systems contribute over $40 \%$ of wheat production in the developing world $[1,2]$. To meet the growing wheat demand, the global production need an $1.6 \%$ to $2.6 \%$ annual growth rate, which can be mainly achieved through improvement in input use efficiency [1]. However, under the current production practices, crop productivity and input use efficiency has decreased/stagnated. In the IndoGangetic Plains (IGP), ground water is being depleted 13 to $17 \mathrm{~km}^{3} \cdot \mathrm{yr}^{-1}$ (Mathew Rodell et al. 2009) coupled with diminishing factor productivity [3], an accelerated growth in crop productivity needs an enhanced resource use effi- ciency to meet the future wheat demand in the region. The improvement of input use efficiency in wheat cropping systems can be achieved through two main strategies: by adopting precise and more efficient crop management practices and germplasm [4]. Although both are important, this paper will focus on improving input use efficiency (specifically, of water \& nutrients) through layering precision-conservation agriculture based crop management approaches.

Wheat being a densely planted crop, limits the use of micro-irrigation by the producers due to economic concerns. Hence, the surface irrigation remains a major irrigation system for densely planted crops and the efficiency of external inputs is mainly relying on the irrigation and soil moisture. Majority of the wheat growers in 
the IGP practice surface irrigation either through flood or check basin methods. The light textured soils under undulating topography leads to uneven distribution of water, which limits the availability of water and nutrients to the crop plants. Undulated crop fields when managed with flood irrigation, also lead to within field spatial variability in grain production owing to leaching of certain nutrients due to excess water at lower elevations and inadequate availability of irrigated water at higher elevations.

Raised bed planting systems has been used since time immemorial by farmers in many parts of the world [5]. Their application have traditionally been associated with water management issues, to reduce the adverse impact of excess water on crop production or to irrigate crops in semi-arid and arid regions [6] where water productivity is comparatively low. A widely used application of raised beds in many semi-arid and arid areas is to plant crops on the edges of beds or ridges that are formed between furrows that carry irrigation water. With the lessons learnt from Mexico (semi-arid, sub-topical highlands), the raised bed planting system is being evaluated and advocated for many crops including wheat in south Asia [7$11]$.

Precision land leveling using laser assisted land leveler equipped with drag scrapper is a process of smoothening the land surface within $\pm 2 \mathrm{~cm}$ of its average micro-elevation. It is contemplated that laser levelers may play a significant role in improving resource use efficiency under surface irrigated systems in the IGP. Reference [12] rated the development of laser technology for precision land leveling as second only to breeding of high yielding crop varieties. Improvement in operational efficiency [13-15], weed control efficiency [16], water use efficiency [14,17-20], nutrient use efficiency [21], crop productivity and economic returns [13,21], and environmental benefits [22] been reported as a result of precision land leveling when compared to traditional practice of land leveling.

In the recent years, planting of wheat on raised bed is being advocated in South Asia for improving resource use efficiencies, especially water use efficiency (WUE). While, significant increase in WUE on laser level fields has been reported by several researchers under different soil and climatic conditions $[18,19,23,24]$. However, the results reported for wheat productivity due to raised bed planting technique were quite inconsistent [8,24-26] compared to flat bed planting. Review of the literature indicates that very little to no data exist on application of raised bed planting on a precision laser leveled field. Coupling the two techniques has potential to further enhance the overall resource use efficiencies associated with wheat production in IGP. The objective of this study was to evaluate the effect of precision land leveling and furrow irrigated raised bed planting techniques on productivity and input use efficiency in irrigated wheat on a sandy loam soil of IGP. It is hypothesized that a systematic effort on integrated technologies (precision laser leveling and raised bed furrow irrigation) would improving resources use efficiency under semi-arid sub-tropical climatic conditions of IGP of India.

\section{Material and Methods}

\subsection{Location}

The study was conducted during the winter months (November through April) in 2002, 2003 and 2004, on an experimental farm of the Project Directorate for Cropping Systems Research, Modipuram, India $\left(29^{\circ} 04^{\prime} \mathrm{N}\right.$ latitude, $77^{\circ} 46^{\prime} \mathrm{E}$ longitude and $237 \mathrm{~m} \mathrm{MSL}$ ).

\subsection{Climate}

The climate of the region is broadly classified as semiarid subtropical, characterized by very hot summers and mild winters. The hottest months are May and June when the maximum temperature reaches $46^{\circ} \mathrm{C}$, whereas, during December and January, the coldest months of the year, the temperatures are often recorded below $5^{\circ} \mathrm{C}$ as in 2002-2003 (Figure 1). The average annual rainfall is 863 $\mathrm{mm}, 75 \%$ to $80 \%$ of which is received through the northwest monsoon season from July through September months. The total rainfall received during the crop growth period was $13 \mathrm{~mm}$ and $51 \mathrm{~mm}$, respectively in year 1 and year 2. Figures 1 and 2, present the weekly temperature, rainfall, and relative humidity for the experimental location for the winter months of 2002-2003 and 2003-2004 respectively.

\subsection{Experimental Techniques}

\subsubsection{Treatments}

The experiment consisted of five combinations of land leveling and planting techniques. The treatments were:

$\left(T_{1}\right)$ Precision leveling with raised bed planting (PLRB) with recommended amount of balanced nutrients such as $120 \mathrm{~kg} \cdot \mathrm{N} \cdot \mathrm{ha}^{-1} ; 26 \mathrm{~kg} \cdot \mathrm{P} \cdot \mathrm{ha}^{-1}$ and $50 \mathrm{~kg} \cdot \mathrm{K} \cdot \mathrm{ha}^{-1}\left(\mathrm{~N}_{120}+\mathrm{P}_{26}\right.$ $+\mathrm{K}_{50}$ ).

$\left(\mathrm{T}_{2}\right)$ Traditional leveling with raised beds (TLRB) with $\mathrm{N}_{120}+\mathrm{P}_{26}+\mathrm{K}_{50}$.

$\left(\mathrm{T}_{3}\right)$ Precision leveling with flat beds (PLFB) with $\mathrm{N}_{120}$ $+\mathrm{P}_{26}+\mathrm{K}_{50}$.

$\left(\mathrm{T}_{4}\right)$ Traditional leveling with flat beds (TLFB) with $\mathrm{N}_{120}+\mathrm{P}_{26}+\mathrm{K}_{50}$.

$\left(\mathrm{T}_{5}\right)$ Traditional leveling with flat beds (TLFB) with no fertilizer application $\left(\mathrm{N}_{0}+\mathrm{P}_{0}+\mathrm{K}_{0}\right)$ to be treated as 


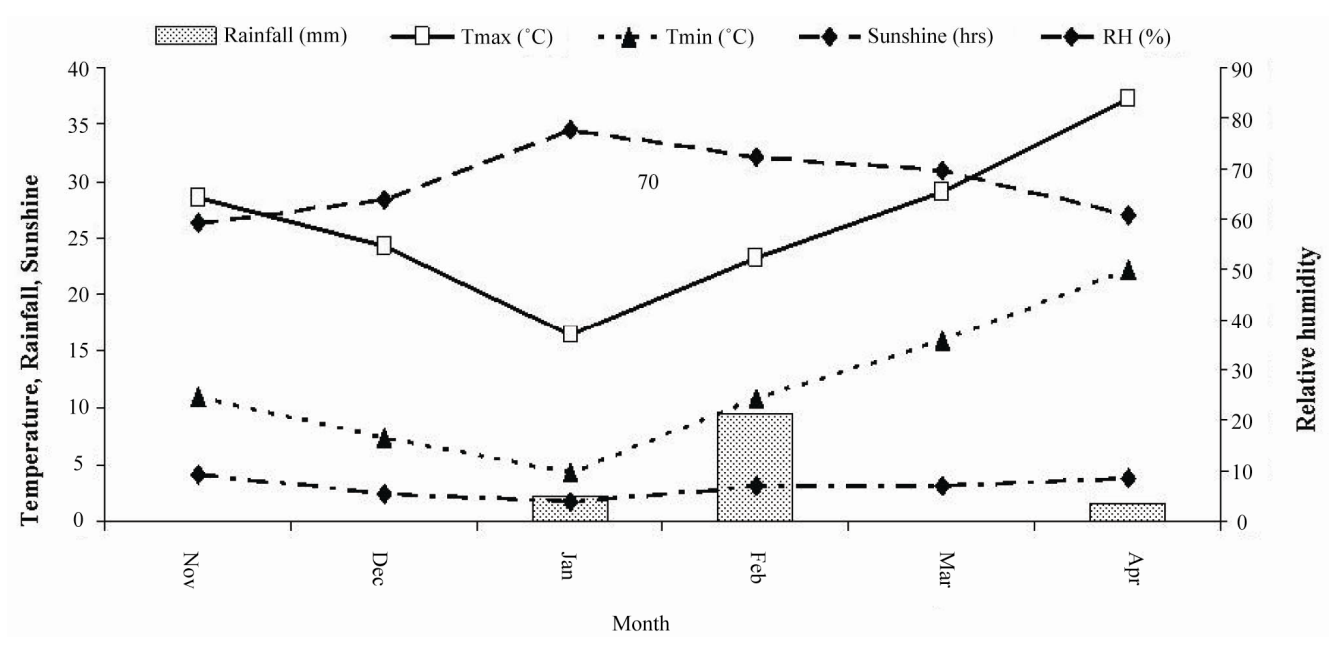

Figure 1. Maximum and minimum temperatures $\left({ }^{\circ} \mathrm{C}\right)$, rainfall $(\mathrm{mm})$, sunshine (hrs) and relative humidity (RH \%) for the winter months of 2002-2003 (year 1).

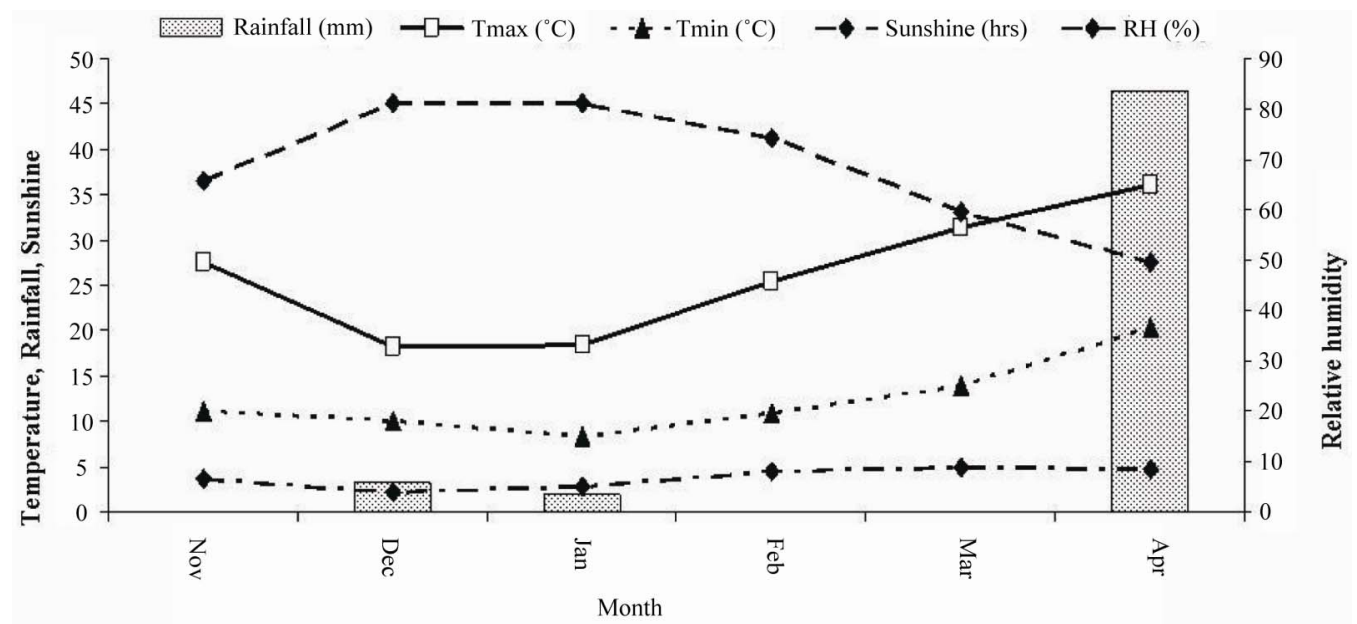

Figure 2. Maximum and minimum temperature $\left({ }^{\circ} \mathrm{C}\right)$, rainfall $(\mathrm{mm})$, sunshine $(\mathrm{hrs})$ and relative humidity $(\mathrm{RH} \%)$ for the winter months of 2003-2004 (year 2).

control. These treatments were laid out in a Randomized Block Design (RBD) with four replications. The size of each plot was $20 \mathrm{~m} \times 10 \mathrm{~m}$ and there were 45 rows of wheat in each plot having $20 \mathrm{~m}$ length.

\subsubsection{Soil Sampling and Analysis}

Before the treatments lay out random soil samples (0 - 15 $\mathrm{cm})$ depth were collected and composited. Composite soil samples were dried, sieved through $2 \mathrm{~mm}$ mesh and were analyzed for texture, $\mathrm{pH}, \mathrm{EC}$, organic carbon, available N, P and K [27]. The soil $(0-15 \mathrm{~cm})$ of the experimental site was typic Ustochrept (sobhapur sandy loam), with a $\mathrm{pH} 8.5$, organic C $0.73 \%$, available N 256 $\mathrm{kg} \cdot \mathrm{ha}^{-1}$, Olsen P $12 \mathrm{~kg} \cdot \mathrm{ha}^{-1}$ and available K $133 \mathrm{~kg} \cdot \mathrm{ha}^{-1}$. The bulk density was measured using core-ring method and one core per stratus of each plot was collected and the samples were oven dried for $48 \mathrm{~h}$ at $105^{\circ} \mathrm{C}$, weighed and bulk density calculated according to reference [28]. The initial bulk density of the soil was $1.48 \mathrm{Mg} \cdot \mathrm{m}^{-3}$. After the wheat harvest, soil samples were collected again and analyzed in an identical manner described above. However, after harvest soil samples were acquired from the raised bed planting treatments, hence the samples were collected from the center of the raised beds.

\subsubsection{Land Leveling}

The land was first ploughed at the field capacity with harrow/cultivator for pulverization and was leveled as per the treatments. A laser equipped drag scrapper $\left(\right.$ Trimble $^{\mathrm{TM}}$, USA) with automatic hydraulic system attached with 60 HP tractor was used for laser land leveling. Before running the laser leveler, the field was sur- 
veyed at 10 feet distance for recording the elevation. The elevation points were averaged to desired elevation for leveling the field. The average elevation value was entered in to the control box for controlling the scrapper at this elevation point $[13,19]$. For the traditional land leveling treatment, the field was first ploughed as described above and was leveled using an iron plank attached to a tractor and was dragged across the land surface.

\subsubsection{Nutrient Application}

Plant nutrients were applied as per the state recommendations for wheat $\left(\mathrm{N}_{120}+\mathrm{P}_{26}+\mathrm{K}_{50}\right)$. $\mathrm{N}_{60}+\mathrm{P}_{26}+\mathrm{K}_{50}$ through urea, di-ammonium phosphate and muriate of potash respectively, were placed in band in seed rows at the time of sowing using ferti-cum-seed drill. The remaining $\mathrm{N}$ was broadcast with dry urea in two equal splits of $30 \mathrm{~kg} \cdot \mathrm{N} \cdot \mathrm{ha}^{-1},\left(\mathrm{~N}_{30}\right)$ at crown root initiation (CRI) and the flag leaf initiation (FLI) crop growth stages.

\subsubsection{Sowing Techniques}

Wheat cultivar PBW-343 was sown on December 4th 2002 using $100 \mathrm{~kg} \cdot$ seed $\cdot \mathrm{ha}^{-1}$. Flat bed planting was done using seed-cum-fertilizer drill at a row spacing of $22 \mathrm{~cm}$. For raised bed planting, seed-cum-fertilizer bed planter was used. The bed: furrow width at top was kept at 37 $\mathrm{cm}: 30 \mathrm{~cm}$ having three seed rows and the depth of the furrow was kept at $15 \mathrm{~cm}$. The plant population was maintained equal in flat as well as raised bed planting.

\subsubsection{Irrigation Application and Water Productivity}

In 2002-2003 wheat was irrigated at the crown root initiation, tillering, jointing, flowering and dough stages that corresponds to Z20, Z29, Z36, Z55 and Z83 [29]. In 2003-2004, the wheat was irrigated at the Z20, Z29, Z55 and Z83 stages. During each irrigation, the water applied to each treatment was measured using Parshall flume [30]. The total water use during the cropping was calculated as $\mathrm{m}^{3} \cdot \mathrm{ha}^{-1}$. The water productivity was calculated as grain yield produced per unit of irrigation water applied during cropping and was converted to $\mathrm{kg} \cdot \operatorname{grain} \cdot \mathrm{m}^{-3}$ water $[31,32]$.

\subsubsection{Plant Growth and Yield Parameters}

The height of five randomly selected plants in each plot $(20 \mathrm{~m} \times 10 \mathrm{~m})$ was recorded at physiological maturity from ground level to tip of the leaf. The effective number of tillers (ear bearing tillers) were counted from an area of $0.25 \mathrm{~m}^{2}$ using $0.50 \mathrm{~m} \times 0.50 \mathrm{~m}$ quadrant at similar locations from where the plant height measurements were recorded. The spike length was measured by taking the spikes from the plants measured for plant height and the same spikes were used for counting the number of grains. The number of grains were counted for five spikes and averaged to convert it on per spike basis. The plants were harvested from the net plot area, air and sun dried for five days and weighed for recording the total biomass. The plants were threshed using mini-plot thresher and the grain weight was recorded on net plot basis. The grain weight was subtracted from the total biomass to get the straw weight. The grain and straw weight from net plot was converted to yield per hectare.

\subsubsection{Plant Analysis and Nutrient Uptake}

The plants measured for growth and yield were used for analyzing the $\mathrm{N}, \mathrm{P}$ and $\mathrm{K}$ content in grain and straw. The grain and straw samples were dried at $70^{\circ} \mathrm{C}$ in a hot air oven. The dried samples were ground in a stainless steel Wiley Mill. The $\mathrm{N}$ content in grain and straw were determined by digesting the samples in sulfuric acid $\left(\mathrm{H}_{2} \mathrm{SO}_{4}\right)$, followed by analysis of total $\mathrm{N}$ by Kjeldahl method [33] using a Kjeltec autoanalyser. The P content (grain and straw) was determined by vanadomolybdophosphoric yellow colour method and the $\mathrm{K}$ content both in grain and straw was analysed in di-acid $\left(\mathrm{HNO}_{3}\right.$ and $\mathrm{HClO}_{4}$ ) digests by Flame Photometeric method [33].

The uptake of the nutrients was calculated by multiplying the nutrient content (\%) by respective yield $\left(\mathrm{kg} \cdot \mathrm{ha}^{-1}\right)$ and was divided by 100 to get the uptake values in $\mathrm{kg} \cdot \mathrm{ha}^{-1}$. The uptake in grain and straw was summed to get the total uptake of nutrientha ${ }^{-1}$.

\subsubsection{Nutrient Use Efficiency}

The agronomic and uptake efficiencies of applied N, P and $\mathrm{K}$ were calculated as presented in Equations 1 and $\mathbf{2}$.

\subsubsection{Data Analysis}

All the data on yield and yield parameters, water productivity, nutrient uptake, nutrient use efficiency and soil parameters were analysed with IRRISTAT for Windows for one-way ANOVA [34]. Duncan's multiple range test (DMRT) was used at the $\mathrm{P}<0.05$ level of probability to test the differences between the treatment means.

\section{Results and Discussion}

\subsection{Plant Growth, Yield Parameters and Yield}

Data pertaining to crop growth and yield parameters of

$$
\begin{aligned}
& \text { Agronomic Efficiency }\left(\mathrm{kg} \cdot \mathrm{kg}^{-1}\right)=\frac{\text { Grain yield of treatment plot }- \text { Grain yield of control plot }}{\text { Quantity of nutrient applied }} \\
& \text { Uptake Efficiency }\left(\mathrm{kg} \cdot \mathrm{kg}^{-1}\right)=\frac{\text { Nutrient uptake treatment plot }- \text { Nutrient uptake in control plot }}{\text { Quantity of nutrient applied }}
\end{aligned}
$$


wheat (Table 1) showed significant variation due to land leveling and planting techniques during both the study years. The plant height recorded at physiological maturity of the crop showed that land leveling with similar crop establishment technique had significant effect on plant height. Maximum plant height was recorded in the "PLRB" planting treatment, which was significantly superior to all other treatments. The number of productive tillers under "PLRB" planting treatment was $9.3 \%$ and 9.8\% higher during yr. 1 (2003-2004) and yr. 2 (20022003), respectively, compared to the "TLRB" planting treatment. The effect of land leveling on productive tillers was more pronounced under flat bed planting. The increase in the number of tillers in "PLFB" planting treatment over the "TLFB" planting treatment was about $12 \%$ for both years. Similarly, land leveling and planting methods showed increased spike length. The longer spikes were recorded with precision land leveling and raised bed planting techniques. The increase in spike length due to precision land leveling was measured at 9.9 and $10.15 \mathrm{~cm}$, respectively during yr. 1 and yr. 2 compared to other treatments. The number of grains/spike with precision land leveling under raised bed planting were $6.3 \%$ and $6.4 \%$ higher over traditional leveling during 2002-2003 and 2003-2004 respectively. Whereas, with PLFB the respective increase in number of grains/ spike was $4.4 \%$ and $3.8 \%$ over traditional leveling (Table 1) treatment.

The yield level, in general, under all the treatments was little higher during yr. 2 compared to yr. 1. This was attributed mainly due to more sunshine hours across the season in yr. 2 compared to yr. 1 (Figures 1 and 2). Also, the minimum temperature during flowering season was higher during yr. 1 compared to yr. 2 (Figures 1 and 2) which limits the reproductive period and responsible for lower yields of wheat. Grain yield of wheat varied significantly due to PLRB techniques and significantly higher yield levels of 5.0 and $5.19 \mathrm{t} \cdot \mathrm{ha}^{-1}$ were recorded under PLRB during yr. 1 and yr. 2, respectively com- pared to other treatments. The increase in grain yield with PLRB was $8.0 \%$ and $8.7 \%$ during yr. 1 and yr. 2, respectively whereas the corresponding increase under flat bed planting was recorded at $6.5 \%$ and $7.5 \%$. The yield under TLRB and PLFB did not varied significantly during both the years. Further, with the same level of land leveling and different levels of planting techniques, the wheat yield varied remarkably. Raised bed showed $8.70 \%$ and $8.58 \%$ yield advantage over flat bed planting under precision leveling during yr. 1 and yr. 2, respectively whereas, the corresponding increase in yield under traditional leveling was recorded at $6.98 \%$ and $7.24 \%$. It showed that the raised bed planting technique is more advantageous under precisely leveled fields.

Significantly higher yield of wheat was recorded with precision land leveling as it takes care of maintaining near homogeneity by way of cut and fill and also tillage [35]. The formation of fragipan and duripan are two important diagnostic horizons responsible for formation of hard pans/crusts on the surface soils of semi-arid zones as in our experimental site due to accumulation of salts [36]. Precision land leveling helps in the removal of these hard sub-surface layers by way of deep tillage and subsequent leveling. The frequent micro-relief which is a common characteristic of saline-alkaline soils as at the study site, is also eliminated through laser leveling. The precision land leveling helps in uniform distribution of water even if the depth of application of water is less (about $5 \mathrm{~cm}$ ) that facilitates good establishment of wheat in sodic soils [37] that resulted in higher yields. The uniformity of land surface with precision land leveling also lowers the within field yield variability compared to traditional leveling [22] that in-turn leads to uniform germination, crop establishment and higher crop yields. The significant increase in wheat yield on raised beds compared to conventional flat planting was attributed due to significantly higher productive tillers, length of spike and number of grains/spike as presented in Table 1. These findings are in agreement with reference $[10,24,26]$ who

Table 1. Effect of laser land leveling and planting techniques on growth and yield of wheat.

\begin{tabular}{|c|c|c|c|c|c|c|c|c|c|c|c|c|}
\hline \multirow[t]{2}{*}{ Treatment } & \multicolumn{2}{|c|}{$\begin{array}{l}\text { Plant height at harvest } \\
\qquad(\mathrm{cm})\end{array}$} & \multicolumn{2}{|c|}{$\begin{array}{l}\text { Productive tillers } \mathrm{m}^{-2} \\
\text { (Nos) }\end{array}$} & \multicolumn{2}{|c|}{ Length of spike $(\mathrm{cm})$} & \multicolumn{2}{|c|}{ Grains/spike (Nos) } & \multicolumn{2}{|c|}{ Grain yield $\left(\mathrm{t} \cdot \mathrm{ha}^{-1}\right)$} & \multicolumn{2}{|c|}{ Straw yield $\left(\mathrm{t} \cdot \mathrm{ha}^{-1}\right)$} \\
\hline & $2002-2003$ & 2003-2004 & $2002-200$ & $2003-2004$ & $2002-2003$ & 3 2003-2004 & $2002-200$ & $32003-2004$ & $2002-2003$ & 3 2003-2004 & $2002-200$ & $003-2004$ \\
\hline $\mathrm{T}_{2}$ & $87.9^{c}$ & $90.1^{\mathrm{b}}$ & $282^{c}$ & $285^{\mathrm{b}}$ & 9.7 & $9.90^{\mathrm{ab}}$ & $41.4^{\mathrm{c}}$ & $43.45^{b}$ & $4.60^{\mathrm{b}}$ & $4.74^{\mathrm{b}}$ & $5.30^{\mathrm{b}}$ & $5.44^{\mathrm{b}}$ \\
\hline $\mathrm{T}_{3}$ & $95.5^{\mathrm{b}}$ & $97.5^{\mathrm{c}}$ & $300^{\mathrm{b}}$ & $305^{\mathrm{c}}$ & 9.8 & $9.93^{\mathrm{ab}}$ & $43.0^{\mathrm{b}}$ & $45.07^{\mathrm{c}}$ & $4.60^{\mathrm{b}}$ & $4.78^{\mathrm{b}}$ & $6.20^{\mathrm{a}}$ & $6.41^{\mathrm{a}}$ \\
\hline $\mathrm{T}_{5}$ & $76.1^{\mathrm{d}}$ & $75.7^{\mathrm{e}}$ & $231^{\mathrm{e}}$ & $229^{\mathrm{e}}$ & 9.1 & $8.93^{\mathrm{c}}$ & $39.2^{\mathrm{d}}$ & $38.82^{\mathrm{c}}$ & $2.70^{\mathrm{c}}$ & $2.64^{\mathrm{d}}$ & $2.90^{\mathrm{d}}$ & $2.88^{\mathrm{d}}$ \\
\hline$S E \pm$ & 0.76 & 0.56 & 3.06 & 2.42 & 0.21 & 0.138 & 0.383 & 0.328 & 0.165 & 0.111 & 0.184 & 0.102 \\
\hline
\end{tabular}

Means with the same letters are not significantly different at $\mathrm{P}=0.05$. 
summarized the finding of multi-location trails across IGP and reported higher yield of wheat with raised beds compared to flat sowing.

\subsection{Irrigation Water Use and Water Productivity}

The total irrigation water use was about $20 \%$ higher in yr. 1 than yr. 2 (Table 2) because of one additional irrigation application in yr. 1 owing to non-uniform distribution of rainfall, less number of rainy days and rainfall during the crop growth cycle (Figures 1 and 2). Land leveling and planting technique significantly influenced the total irrigation water use during both the years. The planting techniques had significant influence on water use at same level of land leveling. Raised bed planting helped in saving of $25 \%$ and $29 \%$ irrigation water during yr. 1 and yr. 2 compared to flat planting under precision land leveling. Whereas, the corresponding water saving under traditional leveling was recorded at $38 \%$ and $33 \%$ (Table 2). The results revealed that the saving in irrigation water with raised bed planting technique was more under traditional leveling as in this technique water moves in furrows only. Laser assisted precision land leveling can reduce evaporation and percolation losses from wheat by enabling faster irrigation times and by eliminating depressions and therefore ponding of water in depressions [38] that results in average wheat irrigation water savings of $25 \%$ in comparison with non-laser leveled fields while increasing crop yield by $15 \%$ to $35 \%$ [22,26,39-41]. Higher grain yield and less water use in raised bed planting and precision land leveling compared to other treatments resulted in higher irrigation water productivity $\left(\mathrm{kg} \cdot\right.$ grain $\cdot \mathrm{m}^{-3}$ irrigation water). The water productivity of precision leveling with raised beds was $31 \%$ and $35 \%$ higher yr. 1 and yr. 2, respectively compared to precision leveling with flat sowing and the corresponding increase in WP under traditional leveling with raised beds over traditional leveling with flat planting was $40 \%$ and $37 \%$. The higher irrigation water productivity (WP) during yr. 1 compared to yr. 2 was mainly due to less irrigation water use and higher productivity levels during yr. 2 than yr. 1.

\subsection{Nutrient Uptake}

Total (grain + straw) uptake of nutrients $(\mathrm{N}, \mathrm{P}, \mathrm{K})$ analyzed at crop maturity varied significantly due to land leveling and planting techniques. Maximum uptake of total $\mathrm{N}$ was recorded with PLRB which was significantly higher over all other treatments during yr. 2 but during yr. 1, it was higher to treatments other than PLFB (Table 3). Similar to nitrogen, maximum uptake of total $\mathrm{P}$ uptake was also recorded in PLRB which was at par to PLFB during yr. 1 but during yr. 2, it was significantly higher over all the treatments (Table 4). The total K uptake by the crop during both the years was, though at par, under precision land leveling irrespective of the planting tech-

Table 2. Effect of laser land leveling and planting techniques on water productivity of wheat.

\begin{tabular}{ccccccc}
\hline \multirow{2}{*}{ Treatment } & \multicolumn{2}{c}{ Total number of irrigations applied } & \multicolumn{2}{c}{ Irrigation water use $\left(\mathrm{m}^{3} \cdot \mathrm{ha}^{-1}\right)$} & Irrigation water productivity $\left(\mathrm{kg} \cdot\right.$ grain $\cdot \mathrm{m}^{-3}$ water $)$ \\
\cline { 2 - 6 } & $2002-2003$ & $2003-2004$ & $2002-2003$ & $2003-2004$ & $2002-2003$ & $2003-2004$ \\
\hline $\mathrm{T}_{1}$ & 5 & 4 & $2635^{\mathrm{d}}$ & $2170^{\mathrm{a}}$ & $1.90^{\mathrm{a}}$ & $2.39^{\mathrm{a}}$ \\
$\mathrm{T}_{2}$ & 5 & 4 & $3335^{\mathrm{c}}$ & $2870^{\mathrm{b}}$ & $1.38^{\mathrm{b}}$ & $1.65^{\mathrm{b}}$ \\
$\mathrm{T}_{3}$ & 5 & 4 & $3525^{\mathrm{b}}$ & $3060^{\mathrm{c}}$ & $1.31^{\mathrm{b}}$ & $1.56^{\mathrm{c}}$ \\
$\mathrm{T}_{4}$ & 5 & 4 & $5270^{\mathrm{a}}$ & $4309^{\mathrm{d}}$ & $0.82^{\mathrm{c}}$ & $1.03^{\mathrm{d}}$ \\
$\mathrm{T}_{5}$ & 5 & 4 & $5270^{\mathrm{a}}$ & $4309^{\mathrm{d}}$ & $0.51^{\mathrm{d}}$ & $0.61^{\mathrm{e}}$ \\
$S E \pm$ & - & - & 15.87 & 11.89 & 0.045 & 0.040 \\
\hline
\end{tabular}

Means with the same letters are not significantly different at $\mathrm{P}=0.05$.

Table 3. Effect of laser land leveling and planting techniques on $\mathbf{N}$ uptake of wheat.

\begin{tabular}{ccccccc}
\hline \multirow{2}{*}{ Treatment } & \multicolumn{5}{c}{ N uptake $\left(\mathrm{kg} \cdot \mathrm{ha}^{-1}\right)$} \\
\cline { 2 - 7 } & $2002-2003$ & $2003-2004$ & $2002-2003$ & $2003-2004$ & $2002-2003$ & Total \\
\cline { 2 - 7 } & $84.51^{\mathrm{a}}$ & $88.28^{\mathrm{a}}$ & $25.86^{\mathrm{a}}$ & $27.24^{\mathrm{a}}$ & $110.37^{\mathrm{a}}$ & $115.52^{\mathrm{a}}$ \\
\hline $\mathrm{T}_{1}$ & $76.36^{\mathrm{b}}$ & $78.93^{\mathrm{b}}$ & $21.21^{\mathrm{b}}$ & $22.05^{\mathrm{b}}$ & $97.57^{\mathrm{b}}$ & $100.98^{\mathrm{b}}$ \\
$\mathrm{T}_{2}$ & $76.83^{\mathrm{b}}$ & $80.11^{\mathrm{b}}$ & $25.45^{\mathrm{a}}$ & $26.92^{\mathrm{a}}$ & $102.27^{\mathrm{ab}}$ & $106.97^{\mathrm{c}}$ \\
$\mathrm{T}_{3}$ & $70.54^{\mathrm{b}}$ & $72.42^{\mathrm{c}}$ & $17.10^{\mathrm{c}}$ & $17.58^{\mathrm{c}}$ & $87.64^{\mathrm{c}}$ & $90.00^{\mathrm{d}}$ \\
$\mathrm{T}_{4}$ & $44.02^{\mathrm{c}}$ & $43.28^{\mathrm{d}}$ & $10.46^{\mathrm{d}}$ & $10.67^{\mathrm{d}}$ & $54.46^{\mathrm{d}}$ & $53.95^{\mathrm{e}}$ \\
$\mathrm{T}_{5}$ & 2.96 & 2.07 & 1.28 & 0.58 & 3.98 & 1.98 \\
$S E \pm$ & 2.96 &
\end{tabular}

Means with the same letters are not significantly different at $\mathrm{P}=0.05$. 
nique (i.e. PLFB and PLRB) but significantly higher over rest of the treatments (Table 5). The higher amount of uptake of nutrients under precision leveling and raised bed planting techniques was associated with higher biomass accumulation under these treatments, which led to higher amount of uptake of these nutrients. The higher nutrient uptake in precision leveling with raised beds is mainly due to less leaching loss of nutrients and availability of sufficient moisture for mineralization of native as well as applied nutrients. The higher uptake efficiency of nutrients depends on a myriod of factors including nutrient availability due to favourable soil biota under precision leveling with raised beds compared to precision leveling with flat beds.

\subsection{Nutrient Use Efficiency}

The agronomic as well as uptake efficiency of applied nutrients was in general higher during yr. 2 compared to yr. 1 due to higher crop yield during yr. 2 with the same level of nutrient application.

\subsubsection{Agronomic Efficiency (AE)}

The agronomic efficiency (AE) of applied nutrients as unit grain production per unit of applied nutrients after deducting the soil supplying capacity was calculated for all the treatments. The AE of applied N (AE-N at 120 $\left.\mathrm{kg} \cdot \mathrm{ha}^{-1}\right), \mathrm{P}\left(A E-P\right.$ at $\left.26 \mathrm{~kg} \cdot \mathrm{ha}^{-1}\right)$ and $\mathrm{K}(A E-K$ at 50 $\mathrm{kg} \cdot \mathrm{ha}^{-1}$ ) was significantly higher under precision leveling with raised bed treatment compared to other treatments during either of the year. The efficiency of the nutrient under PLFB, and TLRB was at par but significantly superior to TLFB during yr. 2. During yr. 1, the efficiency under TLRB, PLFB, and TLFB were at par but significantly inferior to PLRB (Figure 3).

\subsubsection{Uptake Efficiency (UE)}

Precision leveling irrespective of planting technique exerted significant effect on UE-N. The UE-N under PLRB was significantly higher over all other treatments during both the years. Further, the uptake efficiency under PLFB also improved significantly compared to TLRB and TLFB. The uptake efficiency of $P$ was significantly improved with precision leveling compared to traditional leveling irrespective of the planting methods. The UE-P between raised beds \& flat sowing with precision leveling and that of traditional leveling with raised beds and flat sowing did not varied significantly during either of the years of experimentation (Figure 4). The UE-K under precision leveling in either of planting techniques (raised beds and flat sowing) did not varied and was significantly superior to both the planting techniques under traditional leveling (Figure 4).

\subsubsection{Soil Properties}

Significant variations in bulk density, organic carbon, available $\mathrm{N}, \mathrm{P}$ and $\mathrm{K}$ were recorded due to different

Table 4. Effect of laser land leveling and planting techniques on $P$ uptake of wheat.

\begin{tabular}{|c|c|c|c|c|c|c|}
\hline \multirow{3}{*}{ Treatment } & \multicolumn{6}{|c|}{$\mathrm{P}$ uptake $\left(\mathrm{kg} \cdot \mathrm{ha}^{-1}\right)$} \\
\hline & \multicolumn{2}{|c|}{ Grain } & \multicolumn{2}{|c|}{ Straw } & \multicolumn{2}{|c|}{ Total } \\
\hline & $2002-2003$ & 2003-2004 & $2002-2003$ & 2003-2004 & $2002-2003$ & 2003-2004 \\
\hline $\mathrm{T}_{1}$ & $13.03^{\mathrm{a}}$ & $13.38^{\mathrm{a}}$ & $6.02^{\mathrm{a}}$ & $6.11^{\mathrm{a}}$ & $19.05^{\mathrm{a}}$ & $19.49^{\mathrm{a}}$ \\
\hline $\mathrm{T}_{2}$ & $10.61^{\mathrm{b}}$ & $10.56^{\mathrm{bc}}$ & $4.24^{\mathrm{b}}$ & $4.49^{\mathrm{b}}$ & $14.85^{\mathrm{bc}}$ & $15.06^{\mathrm{b}}$ \\
\hline $\mathrm{T}_{3}$ & $11.04^{\mathrm{b}}$ & $11.70^{\mathrm{b}}$ & $5.57^{\mathrm{a}}$ & $5.92^{\mathrm{a}}$ & $16.61^{\mathrm{ab}}$ & $17.62^{\mathrm{c}}$ \\
\hline $\mathrm{T}_{4}$ & $9.49^{\mathrm{b}}$ & $9.74^{\mathrm{c}}$ & $3.61^{\mathrm{b}}$ & $3.57^{\mathrm{b}}$ & $13.10^{\mathrm{c}}$ & $13.31^{\mathrm{d}}$ \\
\hline $\mathrm{T}_{5}$ & $5.42^{\mathrm{c}}$ & $5.50^{\mathrm{d}}$ & $2.31^{\mathrm{c}}$ & $2.16^{\mathrm{c}}$ & $7.74^{\mathrm{d}}$ & $7.66^{\mathrm{e}}$ \\
\hline$S E \pm$ & 0.0876 & 0.57 & 0.38 & 0.44 & 1.15 & 0.703 \\
\hline
\end{tabular}

Means with the same letters are not significantly different at $\mathrm{P}=0.05$.

Table 5. Effect of laser land leveling and planting techniques on $\mathrm{K}$ uptake of wheat.

\begin{tabular}{|c|c|c|c|c|c|c|}
\hline \multirow{3}{*}{ Treatment } & \multicolumn{6}{|c|}{$\mathrm{K}$ uptake $\left(\mathrm{kg} \cdot \mathrm{ha}^{-1}\right)$} \\
\hline & \multicolumn{2}{|c|}{ Grain } & \multicolumn{2}{|c|}{ Straw } & \multicolumn{2}{|c|}{ Total } \\
\hline & $2002-2003$ & 2003-2004 & $2002-2003$ & $2003-2004$ & $2002-2003$ & 2003-2004 \\
\hline $\mathrm{T}_{1}$ & $35.59^{\mathrm{a}}$ & $37.19^{\mathrm{a}}$ & $72.71^{\mathrm{a}}$ & $75.80^{\mathrm{a}}$ & $108.29^{\mathrm{a}}$ & $112.99^{\mathrm{a}}$ \\
\hline $\mathrm{T}_{2}$ & $31.75^{\mathrm{b}}$ & $32.47^{\mathrm{b}}$ & $62.02^{\mathrm{b}}$ & $63.81^{b}$ & $93.77^{\mathrm{b}}$ & $96.28^{\mathrm{b}}$ \\
\hline $\mathrm{T}_{3}$ & $32.22^{\mathrm{ab}}$ & $33.78^{b}$ & $73.18^{\mathrm{a}}$ & $76.22^{\mathrm{a}}$ & $105.40^{\mathrm{a}}$ & $110.02^{\mathrm{a}}$ \\
\hline $\mathrm{T}_{4}$ & $29.26^{\mathrm{b}}$ & $30.16^{\mathrm{c}}$ & $52.24^{\mathrm{c}}$ & $53.35^{\mathrm{c}}$ & $81.51^{\mathrm{c}}$ & $83.49^{\mathrm{c}}$ \\
\hline $\mathrm{T}_{5}$ & $18.10^{\mathrm{c}}$ & $17.91^{\mathrm{d}}$ & $33.35^{\mathrm{d}}$ & $33.27^{\mathrm{d}}$ & $51.45^{\mathrm{d}}$ & $51.17^{\mathrm{d}}$ \\
\hline$S E \pm$ & 1.78 & 0.909 & 2.96 & 1.562 & 4.63 & 2.212 \\
\hline
\end{tabular}

Means with the same letters are not significantly different at $\mathrm{P}=0.05$. 

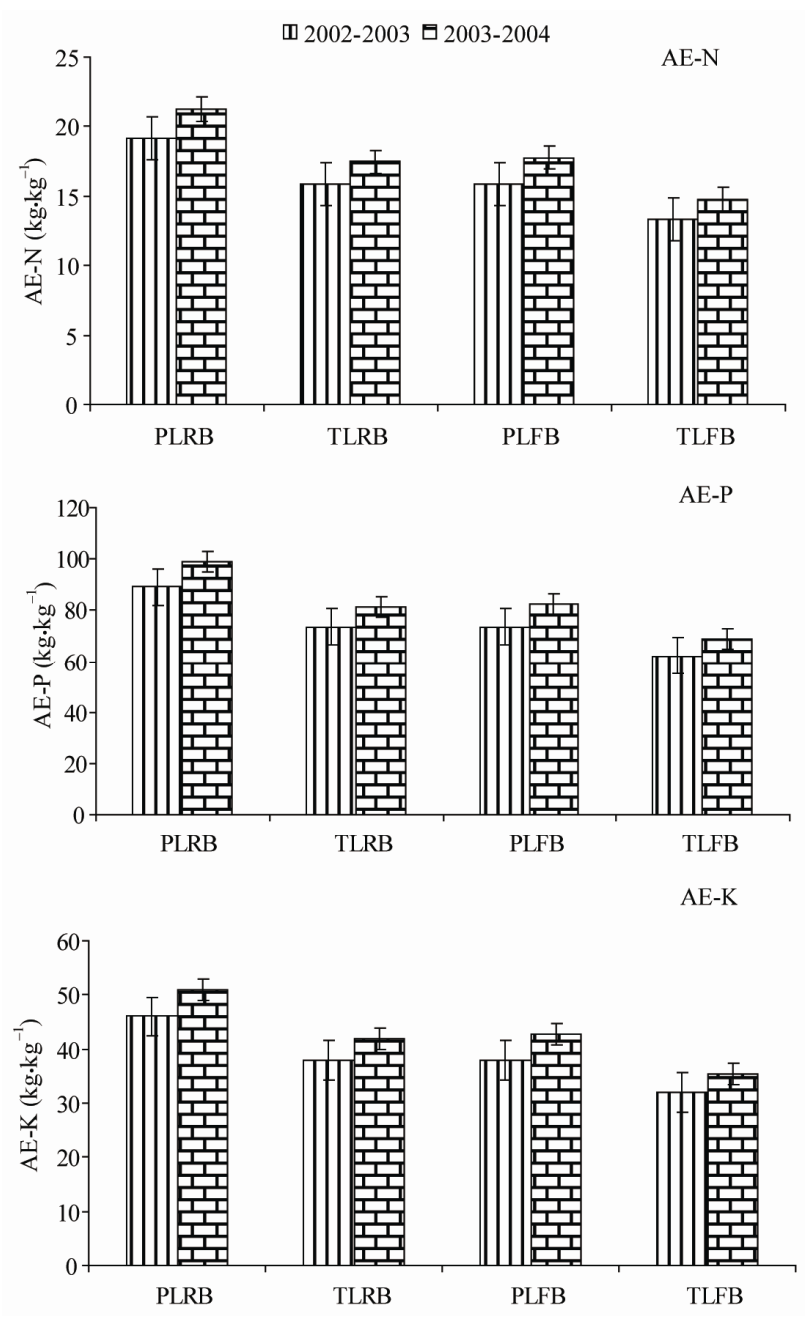

Figure 3. Effect of land leveling and crop establishment on agronomic efficiency of $\mathrm{N}$ (AE-N), P (AE-P) and K (AE-K).

treatments. The bulk density did not varied significantly due to land leveling however, planting techniques had significance influence and it was significantly reduced under raised bed planting compared to flat sowing irrespective of the land leveling practice. This was attributed mainly due to more pore spaces created in the beds through modified land configuration by accumulations the topsoil. Bed planting provides natural opportunity to reduce compaction by confining traffic to the furrow bottoms [42]. The soil organic carbon content in top soil $(0-15 \mathrm{~cm})$ was increased significantly due to raised bed planting compared to flat sowing planting mostly because of localized deposition of more fertile top soil on beds under altered land configuration than flat planting [43]. Available nitrogen, phosphorus and potassium status of soil analyzed after harvest of wheat during both the years showed significant variation due to different
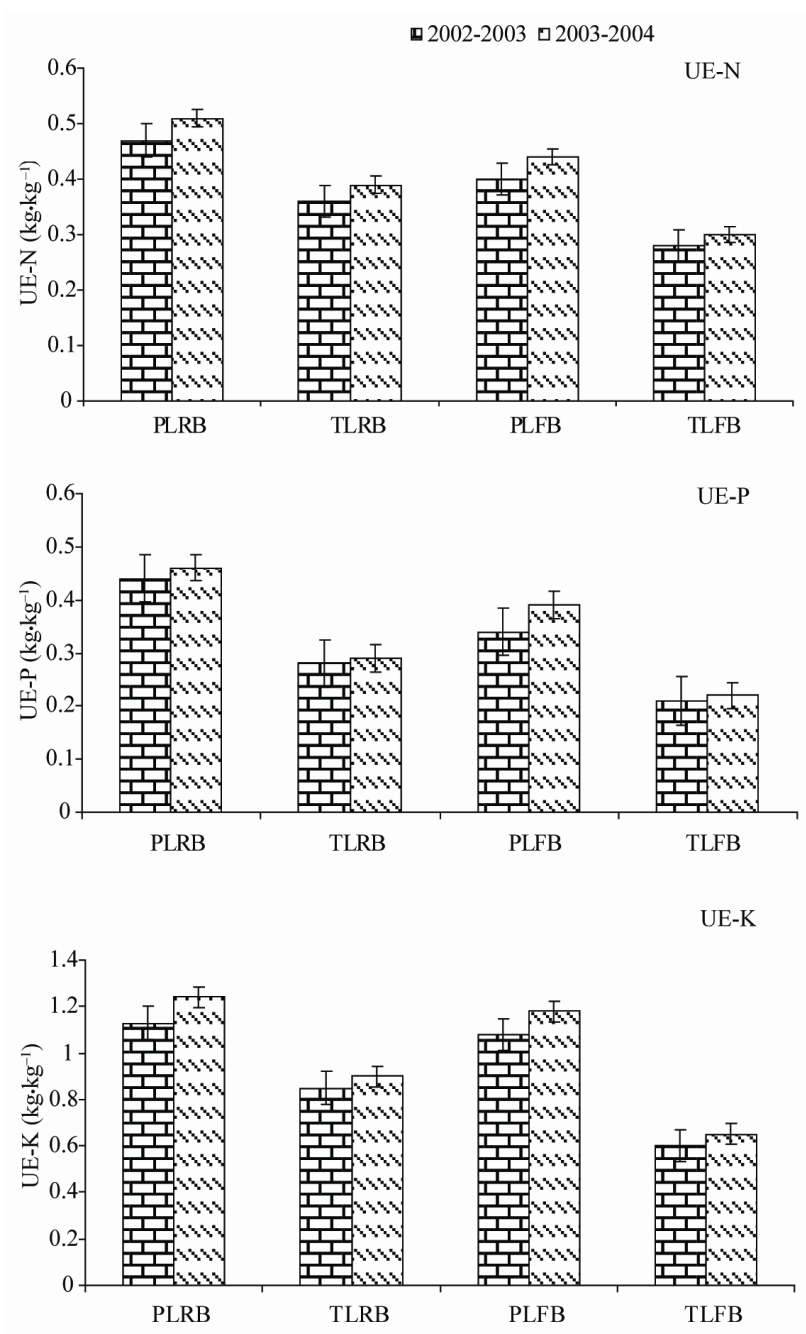

Figure 4. Effect of land leveling and crop establishment on uptake efficiency of $N$ (UE-N), P (UE-P) and K (UE-K).

treatments (Table 6). Maximum available N, P and K content in soil was recorded under PLRB being at par with TLRB but were significantly superior to all other treatments. Further, flat planting either on precision or traditional leveling were at par with each other at similar fertility levels.

\section{Conclusions}

Over the past decade, researchers in association with farmers and entrepreneurs have been trying to overcome the problems of depleting water resources, diminishing input use efficiency, declining farm profitability, and deteriorating soil health by developing, evaluating and refining conservation and precision agriculture-based resource-conserving technologies for the wheat system in the IGP of South Asia. The adoption of raised bed planting within the past decade largely associated with in- 
Table 6. Soil properties after harvest of wheat.

\begin{tabular}{|c|c|c|c|c|c|c|c|c|c|c|}
\hline \multirow[t]{2}{*}{ Treatment } & \multicolumn{10}{|c|}{ Soil properties $(0-15 \mathrm{~cm}) \#$} \\
\hline & $2002-2003$ & $2003-2004$ & $2002-2003$ & $2003-2004$ & $2002-2003$ & $2003-2004$ & $2002-2003$ & $2003-2004$ & $2002-2003$ & 2003-2004 \\
\hline $\mathrm{T}_{1}$ & $1.44^{\mathrm{b}}$ & $1.45^{\mathrm{a}}$ & $0.77^{\mathrm{a}}$ & $0.78^{\mathrm{a}}$ & $258^{\mathrm{a}}$ & $259.25^{\mathrm{a}}$ & $13.2^{\mathrm{a}}$ & $13.3^{\mathrm{a}}$ & $245^{\mathrm{ab}}$ & $244.25^{\mathrm{ab}}$ \\
\hline $\mathrm{T}_{2}$ & $1.44^{\mathrm{b}}$ & $1.45^{\mathrm{a}}$ & $0.78^{\mathrm{a}}$ & $0.79^{\mathrm{a}}$ & $261^{\mathrm{a}}$ & $261.50^{\mathrm{a}}$ & $13.5^{\mathrm{a}}$ & $13.7^{\mathrm{a}}$ & $247^{\mathrm{a}}$ & $245.87^{\mathrm{a}}$ \\
\hline $\mathrm{T}_{3}$ & $1.49^{\mathrm{a}}$ & $1.49^{\mathrm{b}}$ & $0.67^{\mathrm{c}}$ & $0.69^{\mathrm{bc}}$ & $249^{\mathrm{b}}$ & $250.00^{\mathrm{b}}$ & $11.8^{\mathrm{b}}$ & $11.9^{\mathrm{b}}$ & $240^{\mathrm{c}}$ & $240.69^{b}$ \\
\hline $\mathrm{T}_{4}$ & $1.48^{\mathrm{a}}$ & $1.48^{\mathrm{b}}$ & $0.70^{\mathrm{b}}$ & $0.70^{\mathrm{b}}$ & $252^{\mathrm{b}}$ & $250.13^{\mathrm{b}}$ & $12.1^{\mathrm{b}}$ & $12.0^{\mathrm{b}}$ & $243^{\mathrm{bc}}$ & $241.75^{\mathrm{ab}}$ \\
\hline $\mathrm{T}_{5}$ & $1.48^{\mathrm{a}}$ & $1.49^{\mathrm{b}}$ & $0.67^{\mathrm{c}}$ & $0.68^{\mathrm{c}}$ & $243^{c}$ & $139.50^{c}$ & $8.6^{\mathrm{c}}$ & $8.5^{\mathrm{c}}$ & $236^{\mathrm{d}}$ & $232.50^{\mathrm{c}}$ \\
\hline$S E \pm$ & 0.008 & 0.009 & 0.011 & 0.011 & 1.55 & 1.96 & 0.39 & 0.40 & 1.76 & 2.05 \\
\hline
\end{tabular}

Means with the same letters are not significantly different at $\mathrm{P}=0.05$. \#In raised-bed planting, soil samples were collected from the centre of the bed.

creases in farm income related to less use of water and labour. Recently, laser-assisted precision land levelling has shown promise for better crop establishment, water savings and enhanced input use efficiency. This study on the integrated effect of raised bed planting of irrigated wheat on laser levelled fields increased wheat yields (average of 2 yrs) by $16.63 \%$ over flat planting on traditionally levelled fields. Whereas, the yield enhancing effects of precision land levelling alone under raised beds and flat beds were $9.49 \%$ and $8.14 \%$, respectively. The saving in irrigation water with layering of precision-conservation was $49.83 \%$ compared to traditional practice (traditional levelling, flat planting), whereas precision levelling could save $31.26 \%$ water in flat planting and $22.56 \%$ in raised beds. The improvement in nutrient use efficiency was also significant with layering of precision-conservation management compared to individual effects. Therefore, this study confirms that PrecisionConservation Agriculture (PCA) based crop management solutions seem to be promising options to sustain the irrigated wheat systems of South Asia on a long-term basis.

\section{Acknowledgements}

The research was funded by National Agriculture Technology Project (NATP), Indian Council of Agricultural Research, New Delhi, India.

\section{REFERENCES}

[1] S. Rajaram, K. D. Sayre, J. Diekmann, R. Gupta and W. Erskine, "Sustainability Considerations in Wheat Improvement and Production," In: M. S. Kang, Ed., Agricultural and Environmental Sustainability-Considerations for Future, Haworth Food \& Agricultural Products Press, New York, 2007, pp. 105-124.

[2] P. L. Pingali and S. Rajaram, "Global Wheat Research in a Changing World: Options and Sustaining Growth in Wheat Productivity," In: P. L. Pingali, Ed., CIMMYT 1998-1999 World Wheat Facts and Trends, CIMMYT, Mexico, 1999.

[3] J. K. Ladha, H. Pathak, A. T. Padre, D. Dawe and R. K. Gupta, "Productivity Trends in Intensive Rice-Wheat
Cropping Systems in Asia”, In: J. K. Ladha, et al., Eds., Improving the Productivity and Sustainability of Rice-Wheat Systems: Issues and Impacts, ASA Spec. Publ. 65, ASA, CSSA and SSSA, Madison, 2003, pp. 45-76.

[4] M. P. Reynolds, J. I. Ortiz-Monasterio and A. McNab, "Application of Physiology in Wheat Breeding," CIMMYT, Mexico, 2001.

[5] B. Govaerts, K. D. Sayre, K. Lichter, L. Dendooven and J. Deckers, "Influence of Permanent Raised Bed Planting and Residue Management on Physical and Chemical Soil Quality in Rainfed Maize/Wheat Systems," Plant and Soil, Vol. 291, No. 1-2, 2007, pp. 39-54. doi:10.1007/s11104-006-9172-6

[6] K. D. Sayre, "Raised Bed Cultivation," In: R. Lal, Ed., Encyclopedia of Soil Science, Marcel Dekker, Inc., New York, 2004.

[7] K. D. Sayre and O. H. Morena Ramos, "Application of Raised Bed Planting Systems to Wheat," Wheat Program Special Rep. 31., CIMMYT, Mexico, 1997.

[8] S. S. Dhillon, P. R. Hobbs and J. S. Samra, "Investigations on Bed Planning System as an Alternative Tillage and Crop Establishment Practice for Improving Wheat Yields Sustainably," Proceedings of the 15th Conference of the International Soil Tillage Research Organization, Fort Worth, 2-7 July 2000.

[9] M. L. Jat, S. Singh, H. K. Rai, R. S. Chhokar, S. K. Sharma and R. K. Gupta, "Furrow Irrigated Raised Bed Planting Technique for Diversification of Rice-Wheat System of Indo-Gangetic Plains," Journal of Japan Association for International Cooperation for Agriculture and Forestry, Vol. 28, 2005, pp. 25-42.

[10] R. Gupta and K. D. Sayre, "Conservation Agriculture in South Asia," Journal of Agricultural Sciences, Vol. 145, 2007, pp. 207-214. doi:10.1017/S0021859607006910

[11] Y. S. Saharawat, Bhagat Singh, R. K. Malik, J. K. Ladha, M. K. Gathala, M. L. Jat and V. Kumar, "Evaluation of Alternative Tillage and Crop Establishment Methods in a Rice-Wheat Rotation in North Western IGP," Field Crop Research, Vol. 116, No. 3, 2010, pp. 260-267. doi:10.1016/j.fcr.2010.01.003

[12] J. E. Hill, D. E. Bayer, S. Bocchi and W.S. Clampett, "Direct Seeded Rice in the Temperate Climates of Australia," Direct Seeded Flooded Rice in the Tropics, IRRI, Manila, 1991, pp. 91-102.

[13] J. F. Rickman, "Manual for Laser Land Leveling," Rice- 
Wheat Consortium Rice-Wheat Consortium for the IndoGangetic Plains, New Delhi, Technical Bulletin Series 5, 2002, p. 24.

[14] T. B. S. Rajput and Neelam Patel, "Effect of Land Leveling on Irrigation Efficiencies and Wheat Yield," Journal of Soil and Water Conservation, Vol. 3, 2004, pp. 86-96.

[15] T. B. S. Rajput, Neelam Patel and Ghanshyam Agrawal, "Laser Levelling-A Tool to Increase Irrigation Efficiency at Field Level," Journal of Agricultural Engineering, Vol. 41, 2004, pp. 20-25.

[16] M. L. Jat, S. S. Pal, A. V. M. Subba Rao, K. Sirohi, S. K. Sharma and R. K. Gupta, "Laser Land Leveling: The Precursor Technology for Resource Conservation in Irrigated Eco-System of India," Proceedings of the National Conference on Conservation Agriculture, New Delhi, 2004, pp. 9-10.

[17] A. Sattar, F. H. Khan and A. R. Tahir, "Impact of Precision Land Leveling on Water Saving and Drainage Requirement," Journal of AMA, Vol. 34, 2003, pp. 39-41.

[18] M. L. Jat, S. K. Sharma, R. K. Gupta, K. Sirohi and P. Chandana, "Laser Land Leveling: The Precursor Technology for Resource Conservation in Irrigated Eco-System of India," In: I. P. Abrol, et al., Eds., Conservation Agriculture-Status and Prospects, CASA, New Delhi, 2005, pp. 145-154.

[19] M. L. Jat, M. K. Gathala, J. K. Ladha, Y. S. Saharawat, A. S. Jat, Vipin Kumar, S. K. Sharma, V. Kumar and R. Gupta, "Evaluation of Precision Land Leveling and Double Zero-Till Systems in the Rice-Wheat Rotation: Water Use, Productivity, Profitability and Soil Physical Properties," Soil and Tillage Research, Vol. 105, No. 1, 2009, pp. 112-121. doi:10.1016/j.still.2009.06.003

[20] M. L. Jat, R. Gupta, P. Ramasundaram, M. K. Gathala, H. S. Sidhu, S. Singh, R. G. Singh, Y. S. Saharawat, V. Kumar, P. Chandna and J. K. Ladha, "Laser Assisted Precision Land Leveling: A Potential Technology for Resource Conservation in Irrigated Intensive Production Systems of Indo-Gangetic Plains," In: J. K. Ladha, et al., Eds., Integrated Crop and Resource Management in the Rice-Wheat System of South Asia, International Rice Research Institute, Los Banos, 2009, pp. 223-238.

[21] M. A. Choudhary, M. A. Gill, A. Kahlown and P. R. Hobbs, "Evaluation of Resource Conservation Technologies in Rice-Wheat System of Pakistan," Proceedings of the International Workshop on Developing an Action Program for Farm Level Impact in Rice-Wheat System of Indo-Gangetic Plains, 25-27 September 2000, New Delhi, p. 148.

[22] M. L. Jat, P. Chandana, S. K. Sharma, M. A. Gill and R. K. Gupta, "Laser Land Leveling-A Precursor Technology for Resource Conservation," Rice-Wheat Consortium Technical Bulletin Series 7, Rice-Wheat Consortium for the Indo-Gangetic Plains, New Delhi, 2006.

[23] R. K. Gupta, R. K. Naresh, P. R. Hobbs, Z. Jiaguo and J. K. Ladha, "Sustainability of Post Green Revolution Agriculture: The Rice-Wheat Cropping Systems of the IndoGangetic Plains and China," In: J. K. Ladha, et al., Eds., Improving the Productivity and Sustainability of Rice-
Wheat Systems: Issues and Impact, ASA, Spec. Publ. 65, chapter 1:, ASA Madison, 2003, pp. 1-25.

[24] M. L. Jat, M. K. Gathala, K. K. Singh, J. K. Ladha, S. Singh, R. K. Gupta, S. K. Sharma, Y. S. Saharawat and J. P. Tetarwal, "Experiences with Permanent Beds in the Rice-Wheat System of the Western Indo-Gangetic Plain," In: E. Humphreys and C. Roth, Eds., Permanent Beds and Rice-Residue Management for Rice-Wheat System of the Indo-Gangetic Plain, ACIAR Proceedings, Vol. 127, 2008, pp. 98-107.

[25] P. R. Hobbs and R. K. Gupta, "Resource Conserving Technologies for Wheat in the Rice-Wheat System," In: J. K. Ladha, et al., Eds., Improving the Productivity and Sustainability of Rice-Wheat Systems: Issues and Impact, ASA, Spec. Publ. 65, chapter 7, ASA Madison, 2003, pp. 149-171.

[26] L. Bhushan, J. K. Ladha, R. K. Gupta, S. Singh, A. T. Padre, Y. S. Saharawat, M. Gathala and H. Pathak, "Saving of Water and Labour in a Rice-Wheat System with No-Tillage and Direct Seeding Technologies," Agronomy Journal, Vol. 99, No. 5, 2007, pp. 1288-1296. doi:10.2134/agronj2006.0227

[27] D. W. Nelson and L. E. Sommers, "Total Carbon, Organic Carbon and Organic Matter," In: D. L. Sparks, ed., Methods of Soil Analysis, Part 3, SSSA Book Series SSSA, ASA, Madison, No. 5, 1996, pp. 961-1010.

[28] G. R. Blake and K. H. Hartge, "Bulk Density," In: A. Klute, et al., Eds., Methods of Soil Analysis, Part I, ASA and SSSA, Madison, 1986, pp. 363-375.

[29] J. C. Zadoks, T. T. Chang and C. F. Konzak, "A Decimal Code for the Growth Stages of Cereals," Weed Research, Vol. 14, No. 6, 1974, pp. 415-421. doi:10.1111/j.1365-3180.1974.tb01084.x

[30] R. L. Parshall, "Measuring Water in Irrigation Channels with Parshall Flumes and Small Weirs," USDA Circular, No. 843, 1950.

[31] D. Molden and R. Shaktivadivel, "Water Accounting to Assess Use and Productivity of Water," Water Resources Development, Vol. 15, No. 1-2, 1999, pp. 55-71. doi:10.1080/07900629948934

[32] J. W. Kijne, R. Barker and D. Molden, "Water Productivity in Agriculture: Limits and Opportunities for Improvement," Wallingford, 2003, p. 332.

[33] A. L. Page, R. H. Miller and D. R. Keeney, "Methods of Soil Analysis. Part 2. Chemical and Microbiological Properties," 2nd edition, Agronomy Monograph, No. 9, ASA, CSSA, and SSSA, Madison, 1982.

[34] IRRI, "IRRISTAT for Windows," A Statistical Package for Analysis of Data, IRRI, Manila, 2005.

[35] M. L. Jat, S. S. Pal, A. V. M. Subba Rao and S. K. Sharma, "Improving Resource Use Efficiency in Wheat through Laser Land Leveling in an Ustochrept of Indo-Gangetic Plain," Proceedings of the National Seminar on Developments in Soil Science, 68th Annual Convention of the Indian Society of Soil Science, Kanpur, 4-8 November 2003, 2003. 
[36] Salinity Laboratory Staff, "Diagnosis and Improvement of Saline and Alkali Soils," Agriculture Handbook No. 60, USDA, US Government Printing Office, Washington, D. C., 1954.

[37] N. K. Tyagi, "Effect of Land Surface Uniformity on Irrigation Quality and Economic Parameters on Sodic Soils under Reclamation," Irrigation Science, Vol. 5, 1984, pp. 151-166. doi:10.1007/BF00264604

[38] E. Humphreys, S. Thaman, A. Prashar, P. R. Gajri, S. S. Dhillon, Yadvinder-Singh, V. K. Nayyar, J. Timsina and Bijay-Singh, "Productivity, Water Use Efficiency and Hydrology of Wheat on Beds and Flats in Punjab, India," CSIRO Land and Water Technical Report 03/04, CSIRO Land and Water, Griffith, 2004.

[39] M. A. Kahlown, M. A. Gill and M. Ashraf, "Evaluation of Resource Conservation Technologies in Rice-Wheat System of Pakistan," Pakistan Council of Research in Water Resources (PCRWR), Research Report-I, PCRWR, Islamabad, 2002.

[40] M. M. Alam, J. M. Asim and Z. I. Raza, "Economic
Evaluation of Resource Conserving Technologies in Rice-Wheat Cropping System," MERP Publication, WAPDA, No. 255, 2003.

[41] R. K. Gupta and A. Seth, "A Review of Resource Conserving Technologies for Sustainable Management of the Rice-Wheat Cropping Systems of the Indo-Gangetic Plains," Crop Protection, Vol. 26, 2007, pp. 436-447. doi:10.1016/j.cropro.2006.04.030

[42] B. Govaerts, K. D. Sayre, J. M. Ceballos-Ramirez, M. L. Luna-Guido, A. Limon-Ortega, J. Deckers and L. Dendooven, "Conventionally Tilled and Permanent Raised Beds with Different Crop Residue Management: Effect on Soil C and N Dynamics," Plant and Soil, Vol. 280, 2006, pp. 143-155. doi:10.1007/s11104-005-2854-7

[43] T. W. Walker, W. L. Kingery, Joe E. Street, M. S. Lox, J. L. Oldham, P. D. Gerard and F. X. Han, "Rice Yield and Soil Chemical Properties as Affected by Precision Land Leveling in Alluvial Soils," Agronomy Journal, Vol. 95, 2003, pp. 1483-1488. doi:10.2134/agronj2003.1483 